JNUS:Journal of Nahdlatul Ulama Studies Vol. 2, No. 1, Januari 2021: p. 35-46. DOI: 10.35672/jnus.v2i1.35-46

Website: http://jnus.lakpesdamsalatiga.or.i d/index.php/jnus/index

\title{
The National Role of KH. A. Abdul Wahid Hasyim in Keeping the Nation Integrity
}

\author{
Muhammad Syaiful Muhtar \\ PMII City of Salatiga \\ saifulmucbtar76@gmail.com
}

\begin{abstract}
This article examines the national role of KH. A. Wahid Hasyim, especially at the beginning of Indonesia's independence. This study is motivated by the scarcity of studies related to the contribution of figures from Islamic boarding schools in national studies, and at the same time the role of this figure is recognized in the form of an award as a national hero. This is library research with analytical descriptive analysis techniques. The research findings showed that at the young age, the national role of $\mathrm{KH}$. A. Wahid Hasyim appears in his efforts to maintain the unity and integrity of Indonesia through his moderate Islamic thinking, neither right nor left extreme. This was proven by his position as one of the independence committees (BPUPKI), and one of his policies was to approve the elimination of seven words in the Jakarta Charter agreement.
\end{abstract}

Keywords: Wahid Hasyim; Pioneer; National Unity.

\begin{abstract}
Abstrak
Artikel ini membahas tentang peran nasional KH. A. Wahid Hasyim, khususnya pada awal kemerdekaan Indonesia. Kajian ini dilatarbelakangi oleh masih minimnya kajian terkait kontribusi tokoh pesantren dalam kajian nasional, sekaligus diakui perannya dalam bentuk penghargaan sebagai pahlawan nasional. Ini adalah penelitian pustaka dengan teknik analisis deskriptif analitik. Hasil penelitian menunjukkan bahwa di usia muda, KH. A. Wahid Hasyim muncul dalam upayanya menjaga persatuan dan kesatuan Indonesia melalui pemikiran Islam moderat, baik ekstrim kanan maupun ekstrim. Hal itu dibuktikan dengan posisinya sebagai salah satu Badan Pengawas Kemerdekaan (BPUPKI), dan salah satu kebijakannya adalah menyetujui penghapusan tujuh kata dalam perjanjian Piagam Jakarta.
\end{abstract}

Kata Kunci: Wabid Hasyim, Pelopor, Persatuan Bangsa. 
JNUS: Journal of Nahdlatul Ulama Studies, Vol. 2, No. 1, Januari 2021: 35-46

\section{INTRODUCTION}

Currently, Indonesia has reached the age of 74 years, since the independence of the Republic of Indonesia was proclaimed by Bung Karno. In its historical journey, Indonesian independence has gone through various phases and dynamic conflicts. Independence does not solely make the journey of this nation smooth with the goals and ideals stated in the text of the proclamation and the 1945 constitution. Basically, social conflicts and life inequalities that exist in society continue to experience turmoil and very tough obstacles.

Some regions in Indonesia such as Maluku, Poso, Kalimantan and Papua, at the beginning of the transition period due to colonialism to the phase of independence and the concept of democracy were often hit by social conflicts, differences of opinion, and others. However, in the context of current developments, the people in these areas have improved in terms of education, social life, economic structure, politics, and so on. This is proven that Indonesia is still capable of being a country that can solve various araising conflicts. Post-conflicts are not merely resolved, but one thing that needs to consider is how the community can understand the substance of unity that exists in the nation's ideology, namely Pancasila. Then one of the main principles is to realize diversity or what we call binheka tunggal ika that can become an essence of human rights in building an intact Indonesia.

On its journey, Indonesia experienced a very long colonialism by the Dutch, and it has impact on continuing to colonize the Asian nation itself, namely the Japanese nation. The suffering experienced by the Indonesian society was very hard and filled with flowing blood. Japan colinized Indonesia more rapidly from 1942 to 1945 or about three and a half years compared to the position of the Dutch which was up to three and a half centuries (Simatupang, 1981: 59). The colonialism in Indonesia caused deep wounds for the society of Indonesia itself. They felt the pain of suffering, oppression, and arbitrariness. As a result, they tried to defend againts Japanese fascism (Rini, 2003: 55).

The same fate as a colonized nation triggered many figures that were able to change the paradigm of Indonesian society. So the idea of nationalism and unity appeared as a form of resistance to fight the 
oppression and colonial cruelty. There were youth groups who had the idea of being independent from a secular nationalist perspective and religious nationalists or Islamic nationalists. We could see this Islamic nationalist in the history and progress of KH. A. Wahid Hasyim in fighting for independence together with other figures.

Abdul Wahid Hasyim is the fifth son of the KH. Hasyim Asy'ari with Nyai Nafiqah. Wahid Hayim was born on Friday, June 1, 1914 M / 5 Rabiul Awal $1333 \mathrm{H}$ in Tebuireng Jombang (Azra, 1998: 99). When he was five years old, Wahid Hayim learned to read the Al-Qur'an from his father. He also learned to read the books of Fathul-Qarib, Minhajul Qawim and Mutammimah at the age of seven (Rifa'i: 2019: 32).

Since his young age, Wahid Hayim had been very passionate about gaining knowledge and seeking the blessings of teachers. In his history, as an obedient Muslim, Wahid Hasyim studied in many Islamic boarding schools (Rifa'i, 2009: 22-23). His enthusiasm for learning is never low, especially in self-taught learning. His learning pattern made him successful. Even though he did not attend school at the Dutch East Indies Education Institute, he was able to master English and Dutch at the age of 15 (Herry, 2000: 35).

In the midst of various national problems, especially nationalism and religion, it is necessary to re-present the roles and thoughts of figures whom the author considers to have contributed to the nation, which is the end of the sectarian conflicts arising among them. From this point of view, the author tried to conduct scientific research on thought of a national hero, KH. Wahid Hasyim in the context of unity and peace for the integrity of Indonesia. This effort is to help people interpret the importance of unity in the frame of diversity and Pancasila in the current millennial era.

\section{RESULTS AND DISCUSSIONS}

\section{The Young Age of KH. A Wahid Hasyim: Uniting the Indonesian} Nation

The twentieth century is the resurrection and golden age for the Indonesian society in the history of their struggle to form an independent state. At the beginning of the twentieth century, the strategy and format of the movement against colonialism were well organized and structured. 
JNUS: Journal of Nahdlatul Ulama Studies, Vol. 2, No. 1, Januari 2021: 35-46

Many figures intensified unions or associations in the form of organizations as a means of consolidating the understanding or idea related to independence. Various organizations were esatblished as the driving force with their strategies for fighting for independence according to the ideological basis of the organization (McLellan, 2005: 135).

Wahid Hasyim was a disciplined young man who had broad thinking horizon. This was supported by his activeness in reading and analyzing the current situation. It was started from this point that Wahid Hasyim began to prove his thought in the form of writing he made in 1929 (at the age of 15 years) which was written in a memorial book belonging to his younger brother. Since then, Wahid Hasyim could be said to be a reader and writer (Rifa'i, 2009: 25).

One of the youth figures who appeared in the history of the Indonesian independence movement was A. Abdul Wahid from the Muslim nationalist circle in 1945 . The young man who was familiar with Gus Wahid is the son of KH. Hasyim Asy'ari, one of the founders of the Islamic organization, Nahdlatul Ulama (NU). In 1932 precisely when he was 18 years old, Gus Wahid left for Hajj and studied in Mecca for two years. He also taught in Mecca (Aboebakar, 84). Wahid Hasyim's learning and teaching process made him think broadly, openly, and not fanatically in dealing with a problem. Wahid Hasyim believed that Islam could achieve progress and unity. After returning from Mecca, he felt that it was necessary to put his knowledge into practice by making reforms in the social, religious, political, and educational fields (Rifa'i, 2009: 26).

After learning and returning from Mecca, Wahid Hasyim started his work in various sectors, such as education, social order, politics, and so on. At his young age, he was very active in the reading and writing activities. The ability to speak English, Arabic and Dutch led him to independently study and read various books (Miftahudin, 2017: 37). The broad thinking of Wahid Hasyim was in the spotlight for many figures and people in Indonesia. This was because Wahid Hasyim also produced many of his thoughts in various printed media or newspapers. Many people knew about how Wahid Hasyim expressed his idea for the development of the Indonesian nation which was still colonized.

Wahid Hasyim's self-taught learning outcomes greatly helped him in interacting with people in various countries nncluding in the context of 
diplomacy with the Japanese colonizers. Although he did not bring any academic title, the knowledge Wahid Hasyim gained in Mecca was enormous. With his proficiency in reading the situation, in 1941 Wahid Hasyim had written many works based on his thought. His writings were widely published in Nahdlatul Ulama media and various printed media, including the media owned by NU itself, namely the voice of Nahdlatul Ulama (Nugroho, 2017: 62).

Wahid Hasyim was a very productive young man. As a young Muslim figure, he was also the one who was passionate about building the social order of people's lives. His national spirit could not be separated from his father's understanding, KH. Hasyim Asy'ari as one of the founders of Nahdlatul Ulama. His efforts in developing Islamic education had provided cool air for the Indonesian people. The Islamic education he developed was a manifestation of nationalist Islamic values. Islam is not against a unity in the state. On the other hand, he was also active in providing political views that developed during the Dutch colonial period. This made him well known by various national figures in the Indonesian independence movement.

Wahid Hasyim played an important role in uniting the perceptions of nationalist Muslim with secular nationalist figures in the process of independence of the Republic of Indonesia. At first, Wahid Hasyim proposed a clause in the preamble to the Constitution of the Republic of Indonesia which reads "Ketuhanan dengan kewajiban menjalankan syariat Islam bagi pemeluk-pemeluknya" (Anam, 2014: 212).

KH. A Wahid Hayim was approved by Islamic Nationalists and some nationalists. Bung Karno also agreed on a clause regarding the obligation to live up to Islamic law for its adherents as a leader of the BPUPKI session. However, on July 11, 1945, one of the secular nationalist figures named Laturharhary expressed his objection to the clause. The objections conveyed then became a serious debate among the figures on the BPUPKI committee. It is also a criticism for $\mathrm{KH}$. Wahid Hasyim. Meanwhile, some Islamic figures like H. A Sanoesi and H Bagoes Hadikusumo.

On July 13, 1945, at the BPUPKI session, Wahid Hayim proposed two things to include in the law draft, the basis of state. At the beginning, article 4 paragraph 2 which reads "Only native Indonesians can become 
JNUS: Journal of Nahdlatul Ulama Studies, Vol. 2, No. 1, Januari 2021: 35-46

President and Vice President", with Wahid Hayim's suggestion, it was changed to "Only native Indonesian Muslims can become President and Vice President." Then in article 29 which originally reads "Indonesia guarantees the freedom of every citizen to embrace any religion and to worship according to their respective religions". Because of Wahid Hasyim's proposal, it was changed to "State Religion is Islam, by guaranteeing the freedom of people of other faith" (Ansari, 1981: 30).

The deep thought of KH. A Wahid Hasyim regarding the great Islamic struggle was able to submit this proposal to the Constitution of the Republic of Indonesia. Despite the objections and criticisms, Wahid Hasyim's proposal was approved by the BPUPKI committee. This was because Wahid Hasyim also believed that with this proposal, he did not intend to discredit other minorities. As a Nationalist Islamic figure, Wahid Hasyim had a very important role and influence in representing the voice of Muslims in Indonesia.

After BPUPKI was disbanded by Japan on August 7, 1945, a Preparatory Committee for Indonesian Independence (PPKI) was created, and then Sukarno proclaimed Indonesian Independence on August 17, 1945, whose contents were in accordance with the results of the BPUPKI agreement. However, the day after the proclamation of independence, Wahid Hasyim received information that his proposals would one by one be abolished. This was because Bung Hatta had met with the Opsin Kaigur (Japanese Navy). During the meeting, Opsin provided information stating that the people of eastern Indonesia who were Catholic and Protestant would refuse to enter the Indonesian Republic if the formulation of the constitutional state proposed by Wahid Hasyim was not deleted.

Based on this information, Bung Hatta in the PPKI session on August 18, 1945, negotiated with four representatives of Muslim figures to accept the abolition of Wahid Hasyim's proposal regarding "Ke-Tubanan dengan kwajiban menjalankan syariat Islam bagi pemeluk-pemeluknya". The four Islamic figures who were invited to the negotiations were $\mathrm{Ki}$ Bagoes Hadikusumo, Wahid Hasyim, Kasman Singodimejo, and Teuku Muhammad Hassan. Hatta also suggested the Islamic clauses to be removed, because the people of East Indonesia felt any discrimination (Writer Team, 1970: 130). 
Wahid Hasyim was approximately 31 years old with his passion. Not making him a stubborn person, but a youth and Islamic figure that were tolerant and respected differences. The broad knowledge of Wahid Hasyim made him the first person to agree to the suggestion and proposal of the people of East Indonesia. Wahid Hasyim then persuaded 3 other figures. He believed Ki Bagoes Hadikusumo who strongly agreed with Wahid Hasyim's proposal at the BPUPKI session. (Hatta 1970: 320).

As a National Youth Leader, Wahid Hasyim emphasized unity and peace, rather than defending his idea and proposal although they were agreed by many independence figures. It did not make him arrogant and feel the most victorious of himself. Wahid Hasyim was a humanist and logical figure. On the other hand, Wahid Hasyim had sacrificed and was willing to accept gracefully that his proposal was removed from the State Constitution. He realized that minorities were an important part of the integrity of the nation, anyone with different ethnicity, race and religion, including the nation's children who took part in fighting for the ideals of independence for the Republic of Indonesia.

Wahid Hasyim kept trying to persuade other figures to accept voluntarily the removal of his proposal from the constitution. Wahid Hasyim once conveyed a persuasion to Ki Bagoes Hadikusumo that in essence "the political and security situation at the beginning of the revolution did require national unity and integrity." As a minority group, they could indeed carry out offensive politics, even accompanied by political pressure, as if they were oppressed by the majority. As the group that had interest to establish the unity and integrity in the face of the Dutch, which still had collaborators everywhere, the Islamic and Nationalist leaders fulfilled their demands. It meant that the obligations in carrying out Islamic law for its adherents would be accommodated by implementing Article 29 paragraph 2 of the 1945 Constitution, namely; the state guarantees the freedom of each of inhabitants to embrace their own religion and worship according to that religion and belief (Endang, 1981: 47-50).

The role of Wahid Hasyim was a great historical evidence for the realization of unity between group and religion in Indonesia. Respecting differences with moderate and tolerant thinking had become Hasyim Asy'ari's focus for people all over Indonesia. Wahid Hasyim taught about 
JNUS: Journal of Nahdlatul Ulama Studies, Vol. 2, No. 1, Januari 2021: 35-46

the meaning of unity and peace over group interests. He was not easily offended and mad when his ideas were not approved by minorities. For Wahid Hasyim, the minority group was power to complete the integrity of the nation, state and religion. The character and broad thinking of Wahid Hasyim in fighting for Indonesian independence should be used as an example for society and the young generation to continue to protect Indonesia from conflict and division.

\section{KH. A Wahid Hasyim: Youth Pioneer of the United Nation}

The thought of A. Wahid Hasyim as a Nationalist Islamic figure was one of the manifestations of the dialogue between Islamic thought and western knowledge. The conception of the basis of the state constitution, which was reflected in its role, was a democratic pathway such as a hybrid intellectually. Wahid Hasyim was not such an Islamic thinker who only followed the mainstream. His strict and situational character always strived to fight for values considered correct through constitutional perspectives. However, when the truth was not able yet to be accepted by members of the assembly, he accepted the assembly's decision and ran it according to the principle of maslahah mursalah (Kusuma, 2011: 229).

Wahid Hasyim as a young figure with a santri background had a principle that when there was goodness to avoid damage or division, he always upheld the truth in a constitutional way or used the legal path owned by the state. Wahid Hasyim was not a typical of person who was stubborn and arrogant towards the value of truth. He emphasized the unity and benefit of the people, rather than satisfying one group only. Because Indonesia was like a baby, it needed enough love and attention so that one day it became a strong country.

The contribution of Wahid Hasyim's great thought to the Indonesian nation was to provide a concept or style of thinking and a state which was capable of being a synthesis of the two major mainstreams in viewing the relationship between Islam and the state, between organic and substantive. However, Wahid Hasyim had the most principal character (self-identity), namely, the use of interpretation or scientific logic based on local wisdom.

Wahid Hasyim also thaught that life was a struggle (ijtihad) in a state that could not be separated from the dialectical and demonstrative 
processes, by using siyasah dusturiyyah fil Islam (Islamic political law) which was able to take positive values from the progress of the times, but not leaving local identity and wisdom. The author saw this feature from the discourse of the native heroes of the Republic of Indonesia (Heri, 2003: 118). The younger generation of Indonesia could emulate Wahid Hasyim's state attitude who fought since he was young until he died. Broad thinking would make the attitude more mature and wise in solving problems. It was like what Wahid Hasyim did when he was an important figure in BPUPKI and PPKI.

The disruption era was currently a challenge for the Indonesian people to live peacefully, unite and prioritize the benefit, not the interests or satisfaction of one group. According to Wahid Hasyim's thought, the younger generation could take a positive side to become youth or a society that respected state law, social order, and the various differences or diversity. This was because Wahid Hasyim was an Islamic figure who inherited the thinking construction from his father KH. Hasyim Asy'ari which K.H. Hasyim agreed the Pancasila as the state foundation. It is not because of being part of the majority, but the awareness that no matter how small it was to be part of Indonesia, it must be maintained and fought for.

Wahid Hasyim's thought as a pioneer of national unity could be seen in his work as a religious and educational actor capable of building continuity with the world of politics. The values championed by Wahid Hasyim were very substantial, such as humanity and protection of citizens' rights, as the spirit of formal citizenship matters. This was what then made Wahid Hasyim dare to take a moderation decision to accept changes to the first precepts in the Jakarta Charter.

Wahid Hasyim was a hero figure with all his merits. He was an anti modernity person even though his identity was a traditionalist. However, it was undeniable that Wahid Hasyim was one of the traditionalists who accepted the positive aspects of modernity. It could be known that Wahid Hasyim created Tebuireng pesantren, which was originally and purely using the principle of traditional education of pesantren, and then became an integrated Islamic boarding school with general science teaching, English language teaching. Not only that, Wahid Hasyim also taught students about the organization (Azra, 1998: 103). 
JNUS: Journal of Nahdlatul Ulama Studies, Vol. 2, No. 1, Januari 2021: 35-46

The mindset of Wahid Hasyim proved that not all traditionalist Islamic figures were rigid or against modernity. He rejected the negative side of modernity and took the positive side. Wahid Hasyim reflected a global mindset that he did not leave the local mindset as the identity of the Indonesian perspective. It was this kind of thinking that could be learned from the next generation of the nation. The dynamics of life and the contemplation of the times must be controlled in a wise manner. It was not easy to lose its identity as Indonesians.

\section{CONCLUSION}

Wahid Hasyim was a visionary young man and a true statesman. Although he was still young and had a traditional educational background that did not necessarily prevent him from advancing and contributing to the Indonesian nation. His major decision to propose the abolition of the seven words in the 1945 Constitution showed his moderate thinking and role of a complete nationality, for the sake of the integrity of the nation and the Unitary State of the Republic of Indonesia.

\section{REFERENCES}

Aboe bakar. 2011. Sejarah Hidup KH. A. Wabid Hasjim. Jakarta: Mizan.

Anam, A Khoirul, dkk. 2014. Enslikopedia Nabdlatul Ulama: Sejarab Tokoh dan Khaszanah Pesantren. Jakarta: Yayasan Prapanca.

Anshari, Endang Saifuddin. Piagam Jakarta 22 Juni 1945 dan Sejarah Konsensus Nasional antara Nasionalis Islam dan Nasionalis Sekular, Tentang Dasar Negara Republik Indonesia 1945-1959. Bandung : Pustaka Sleman ITB.

Azra, Azyumardi dan Umam, Saiful. 1998. Menteri-menteri Agama RI: Biografi Sosial Politik. Jakarta : PPIM.

Dewantoro, Nugroho. 2017. Wabid Hasyim Untuk Republik dari Tebuireng: Tokoh Kemerdekaan di Awal Kemerdekaan. Jakarta: Pustaka Gramedia.

Herry, Mohammad, Dkk. T.th. Tokoh-tokoh Islam yang Berpengarub Abad 20. T.Pn.

Hatta, Mohammad. 1981. Memoir. Jakarta: PT Tintamas Indonesia. Miftahuddin. 2017. KH. A Wahid Hasyim Peletak Dasar Islam Nusantara. Bandung: Marja. 
The National Role of KH. A. Abdul Wahid Hasyim....(Muh. Syaiful Muhtar)

McLellan, David. 2005. Ideologi Tanpa Akbir. Alih Bahasa Muhammad Syukri. Yogyakarta: Kreasi Wacana.

Tim Penulis Panitia Peringatan 75 Tahun Kasman. 1970. Hidup Itu Berjuang Kasman Singodimedjo 75 Tabun. Jakarta: Bulan Bintang.

Rifa'i, Mohammad. 2009. Wahid Hasyim; Biografi Singkat 1914 - 1953. Yogyakarta : Garasi.

Simatupang, T.B. 1981. Pelopor dalam Perang Pelopor dalam Damai. Jakarta: Sapdodadi NV.

Yunarti, Rini. 2003. BPUPKI, PPKI, Proklamasi Kemerdekaan RI. Jakarta: Kompas. 